\title{
NISTIR 6582
}

\section{Benefits and Costs of Research: A Case Study of Fire Dynamics Simulation}

Barbara C. Lippiatt

Office of Applied Economics

Building and Fire Research Laboratory

National Institute of Standards and Technology

Gaithersburg, MD 20899-8603

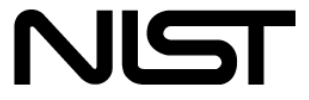

National Institute of Standards and Technology

Technology Administration, U.S. Department of Commerce 


\section{NISTIR 6582}

\section{Benefits and Costs of Research: A Case Study of Fire Dynamics Simulation}

Barbara C. Lippiatt

Office of Applied Economics

Building and Fire Research Laboratory

National Institute of Standards and Technology

Gaithersburg, MD 20899

January 2002

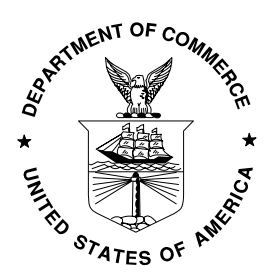

U.S. Department of Commerce Donald L. Evans, Secretary

Technology Administration Phillip J. Bond, Under Secretary for Technology

National Institute of Standards and Technology Arden L. Bement, Jr., Director 


\section{Abstract}

The Fire Safety Engineering Division at the National Institute of Standards and Technology (NIST) has analyzed the interactions of sprinklers, draft curtains and roof heat and smoke vents using newly developed fire modeling software. The software, Fire Dynamics Simulator (FDS), provides means to simulate fire growth and suppression in spaces protected with automatic fire sprinklers. At the request of National Fire Protection Research Foundation (NFPRF), the NIST Building and Fire Research Laboratory (BFRL) assisted in the planning and analysis of industry funded large-scale tests that involved the three fire protection systems. Three fire protection devices were required in warehouses by the Uniform Fire Code (UFC), a prescriptive model code serving over one-third of the Nation: sprinklers, draft curtains, and roof vents. Some property owners considered these multiple requirements to be outdated, overly conservative, and costly. Yet the traditionally-accepted way to evaluate the validity of proposed code changes involves an extensive series of expensive, time-consuming, full-scale tests. In some cases, typical variations in series of large-scale tests have prevented conclusive results to be drawn from pure empirical studies. BFRL, working with industry, provided FDS simulations before each of a limited series of full-scale tests to help design the tests to return the most information possible. The simulation/testing approach proved successful. It yielded enough scientific evidence to help convince UFC code officials to remove draft curtain requirements from sprinklered warehouse facilities. A benefit-cost analysis shows BFRL's contribution yielded a Present Value Net Savings ranging from \$186 million to \$377 million, a Savings-to-Investment Ratio from 50.24 to 100.61, and an Adjusted Internal Rate of Return from $25.1 \%$ to 28.7 \%. The three economic measures of worth indicate that the FDS application was an economically worthwhile effort.

Key words: Building economics; economic analysis; fire protection; fire simulation; impact evaluation; life-cycle costing; safety; warehouse facilities. 


\section{Acknowledgments}

This report could not have been completed without the help of others. The author wishes to thank David Evans and Kevin McGrattan of the NIST/BFRL Fire Safety Engineering Division for their support and for providing the background, insights, and industry contacts necessary to complete the economic analysis. Deserving thanks for their time and willingness to share expertise are interviewees Rick Mulhaupt of the National Fire Protection Research Foundation, William Tomes of TVA, Inc., Craig Beyler of Hughes Associates, Kenneth Linder and Todd Schumann of GE Industrial Risk Insurers, and Dave Nuss, NFPA Regional Manager. Deserving special thanks is Robert Chapman of the NIST/BFRL Office of Applied Economics who led four earlier BFRL impact studies, laying an excellent foundation for launching this study. The author has liberally borrowed from his approach, data sources, and result presentation format. Also deserving thanks are Harold Marshall and Stephen Weber, also of the Office of Applied Economics, for their comments that inspired many improvements. 


\section{Contents}

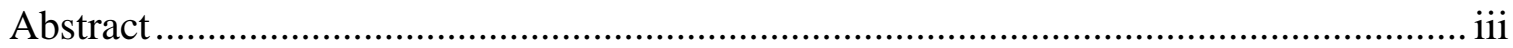

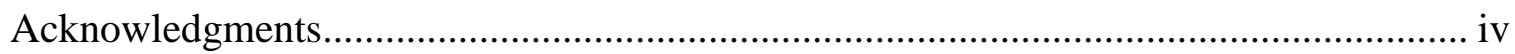

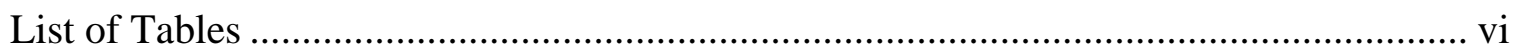

List of Figures and Exhibits .............................................................................. vii

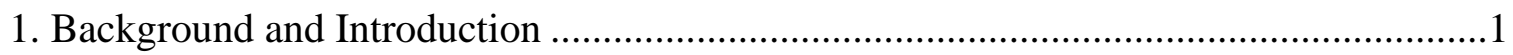

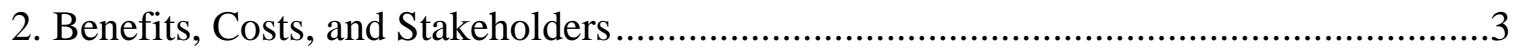

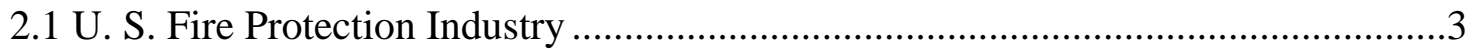

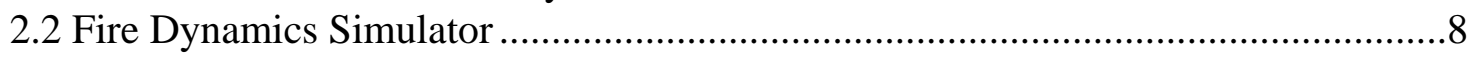

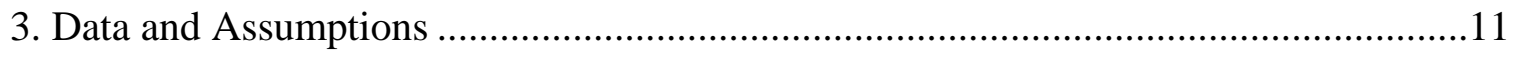

4. Baseline Analysis of Economic Impacts..............................................................17

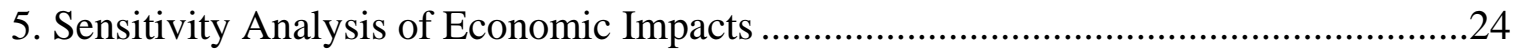

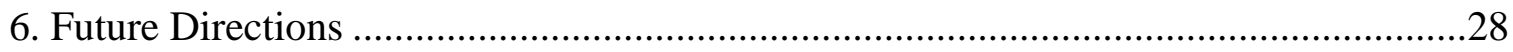

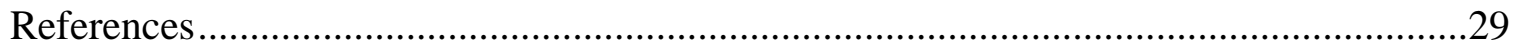




\section{List of Tables}

Table 1. Fire Protection Benefits and Costs by Stakeholder ...............................................

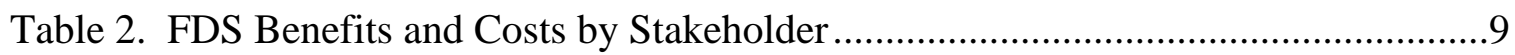

Table 3. Warehouse Floorspace Affected by Uniform Fire Code Change in Millions of Square Meters per Year (million $\mathrm{ft}^{2} / \mathrm{yr}$ ) ...................................................................18

Table 4. Baseline Analysis: Present Value Savings Attributable to BFRL, in 2000 Dollars ..............................................................................................................19

Table 5. Present Value Investment Costs to BFRL, in Millions of 2000 Dollars .............20

Table 6. Sensitivity Analysis: Present Value Savings Attributable to BFRL based on Pessimistic Draft Curtain Savings, in 2000 \$ ..........................................................25

Table 7. Sensitivity Analysis: Present Value Savings Attributable to BFRL based on Optimistic Draft Curtain Savings, in 2000 \$ ...........................................................26

Table 8. Summary: BFRL Contribution to Cost Savings from Removal of Draft Curtain Requirements from Uniform Fire Code, 1996-2020 …………………………….....27 


\section{List of Figures and Exhibits}

Figure 1. Total Warehouse Floorspace by Year of Construction ....................................12

Exhibit 1. Summary of Economic Impacts of BFRL Research on Fire Dynamics Simulation .21 


\section{Background and Introduction}

Through the development of products like the Fire Dynamics Simulation (FDS) software the National Institute of Standards and Technology (NIST) seeks to help fire protection engineers design fire safety systems tailored to individual buildings. FDS packages the latest advances in computer technology with the latest in computational fluid dynamics and fire safety engineering, producing software that simulates fire growth and suppression in facilities protected with automatic fire sprinklers and other fire protection features. These developments are intended to help design fire safety systems of the future that are more effective and economical.

The need for the NIST FDS software stems from significant industry pressures. The cost of fire safety systems installed in the United States exceeds $\$ 21$ billion annually. ${ }^{1}$ Property owners are anxious to provide more cost-effective protection for their facilities against the risk of fire without compromising safety. However, local fire safety requirements are based on prescriptive codes enforced by local authorities. The traditionally accepted way to evaluate the performance of new fire safety systems, justify prescriptive code changes, and demonstrate the acceptance of cost-effective new technology, involves expensive, time-consuming full-scale testing.

For warehouse size facilities, full-scale fire testing typically costs between $\$ 50,000$ and $\$ 75,000$ per test. A series of nominally a dozen full-scale tests is often required to fully evaluate the performance of a proposed fire safety system. In some cases, even a series of 12 tests proves inconclusive; there is no guarantee a testing series will yield the scientific evidence required to enable a code change or validate an existing code. Furthermore, the testing involves many weeks of work to set up elaborate equipment, often an extensive period of taking data, and finally, time to analyze and understand the results. The availability of powerful new computers has the potential to reduce the costs of full-scale fire testing in two ways. First, simulation studies can substitute for some experiments by permitting extrapolation of conditions not actually observed. Several hundred different combinations of variables such as room configuration, load of combustible materials, and air flow can be simulated in a short period of computer time, reducing the need for the full-scale tests to a carefully selected set of critical ones. Computer modeling can also be used to target the most critical parameters for further full-scale testing, thus making more effective use of the full-scale tests. Thus, the computer is a valuable tool in fire research, both to study conditions that are too expensive to test extensively experimentally, and to assist in the design of data collection efforts that are carefully targeted to return the most information within a limited budget.

In 1996, basic FDS research at NIST reached a level of maturity permitting development of a practical application intended to take advantage of the benefits of computer simulation. The application involved simulating the interactions among sprinklers, draft curtains, and roof vents in warehouse facilities. ${ }^{2}$ All three fire protection devices were required in warehouses by the

\footnotetext{
${ }^{1}$ Ramachandran, G. 1998. The Economics of Fire Protection. London: E \& FN Spon, p 18. Annual averages for the years 1991-1993 were converted to 1998 dollars using the U.S. Department of Labor's Consumer Price Index reported at http://stat.bls.gov/cpihome.htm.

${ }^{2}$ McGrattan, K. B., Hamins, A., and D. W. Stroup. 1998. Sprinkler, Smoke and Heat Vent, Draft Curtain
} 
Uniform Fire Code (UFC), which serves as a model code (or one which many local jurisdictions adopt) for about one-third of the Nation. Draft curtains are rows of barriers (typically made of sheet metal) hung vertically from warehouse ceilings to contain the flow of smoke and heat and direct it to roof vents. There was some concern among property owners and sprinkler manufacturers, however, that not only was the UFC requirement for draft curtains in facilities protected with automatic fire sprinklers unnecessary and unduly expensive, but that draft curtains actually hindered the performance of fire sprinklers. But the traditional route for testing the validity of their claims, and collecting the scientific evidence necessary to convince code officials to remove draft curtains requirements, involved prohibitively expensive and perhaps inconclusive full-scale fire testing. The Fire Safety Engineering Division of the NIST Building and Fire Research Laboratory had an opportunity to use its newly developed FDS software to help a National Fire Protection Research Foundation (NFPRF) consortium of industrial facilities owners, fire sprinkler manufacturers, and roof vent manufacturers reduce the expense of fullscale tests, provide greater understanding and confidence in the measured results, and potentially save property owners millions of dollars in draft curtain costs.

The NIST Building and Fire Research Laboratory (BFRL) Office of Applied Economics was asked to estimate the economic impact of this application of the FDS research, that is, of simulating the interactions among sprinklers, draft curtains, and roof vents in warehouses. The measurement of economic impacts of research is a major objective of NIST. Measuring economic impacts is essential to BFRL to help select the "best" among competing research programs, to evaluate how cost effective are existing research programs, and to defend or terminate programs on the basis of their economic impact.

This is the fifth in the current series of impact studies prepared by BFRL. ${ }^{3}$ This study follows the same basic approach as the others by: (1) identifying the benefits, costs, and stakeholders of the FDS program, (2) describing the data and assumptions for the economic impact assessment, (3) conducting a baseline analysis of economic impacts, (4) conducting a sensitivity analysis of economic impacts, and (5) summarizing results in a standardized BFRL Summary Impact Statement. Thus, the results of the FDS economic impact study can be compared to the results of the other studies in the BFRL series.

\footnotetext{
Interaction: Large Scale Experiments and Model Development. NISTIR 6196-1. Gaithersburg, MD: National Institute of Standards and Technology.

${ }^{3}$ Chapman, R. E. 2000. Benefits and Costs of Research: A Case Study of Construction Systems Integration and Automation Technologies in Industrial Facilities. NISTIR 6501. Gaithersburg, MD: National Institute of Standards and Technology; Chapman, R. E. 1999. Benefits and Costs of Research: A Case Study of Cybernetic Building Systems. NISTIR 6303. Gaithersburg, MD: National Institute of Standards and Technology; Chapman, R.E., and S.F. Weber. 1996. Benefits and Costs of Research: A Case Study of the Fire Safety Evaluation System. NISTIR 5863. Gaithersburg, MD: National Institute of Standards and Technology; and Chapman, R. E., and S. K. Fuller. 1996. Benefits and Costs of Research: Two Case Studies in Building Technology. NISTIR 5840. Gaithersburg, MD: National Institute of Standards and Technology.
} 


\section{Benefits, Costs, and Stakeholders}

To understand the context within which the market for the FDS program operates, an economic profile of the U.S. fire protection industry is developed. The profile identifies and defines all the costs and benefits of fire protection, by stakeholder group. It consists of 19 benefits and 27 costs across 6 stakeholder groups. Within this fire protection context, a subset of benefits, costs, and stakeholders are identified as being affected by the overall FDS research program. Within this subset, in turn, the particular benefits and costs affected by the sprinkler/draft curtain/roof vent FDS application are identified. These FDS application benefits and costs are the focus of this case study and will be studied in some detail in the following chapters of this report. Note, however, that the economic profile of the U.S. fire protection industry, as well as the profile of the overall FDS program, provide an efficient starting point for future economic impact studies of other BFRL fire research efforts and other FDS applications.

\subsection{U. S. Fire Protection Industry}

The benefits and costs of fire protection are of two major types: uncertain and certain. Uncertain benefits and costs accrue only when an actual fire occurs. Their amount depends upon the probability of a fire occurring and probable damage if a fire occurs. Uncertain benefits and costs include direct and indirect fire losses. Direct fire losses consist of property damage to a building and its contents. Indirect fire losses are those that occur after a fire has been extinguished, such as income losses and distress accompanying death and injury, and profit and employment losses arising from business disruption.

Certain benefits and costs represent a much larger share of the costs of fire protection. They arise from activities intended to lower a stakeholder's uncertain costs--by lowering the probability of a fire occurring, lowering probable damage, or by transferring uncertain costs to another stakeholder. Examples include insurance premiums, fire services, codes and standards activities, and fire protection technology. Fire protection technology includes both active fire protection measures such as smoke detection and sprinklering systems, and passive measures incorporating protection into the building's structure, materials, and design.

There are six major groups of stakeholders, or groups with an economic interest in fire protection: property owners, the local community, the insurance industry, fire protection device manufacturers, device testing labs, and the Nation. For all stakeholders except the Nation, transfer payments are common. For example, property owners pay insurance premiums to the insurance industry, and pay property taxes to fund fire services for the local community. Or, a large fire may lead to business disruption and its attendant profit and employment losses for one local community that are offset by gains for another. While transfer payments such as these are important to the private sector and the local community, they are irrelevant for a benefit-cost analysis at the societal, or national level. At the national level, a benefit-cost analysis should evaluate only the probable reduction in total fire protection costs due to a change in fire safety technology. ${ }^{4}$ The FDS economic impact study is a benefit-cost analysis at the national level,

\footnotetext{
${ }^{4}$ G. Ramachandran, 1998, p. 15.
} 
accounting for the benefits and costs of all stakeholder groups net of transfer payments.

Table 1 identifies the benefits and costs of fire protection by stakeholder group. In this table, a stakeholder's financial interest (benefit or cost) is denoted by a " $\mathrm{B}$ " for a benefit or "C" for a cost. Summing all benefits (cost savings) and costs across all stakeholders yields the total net cost of fire protection to the Nation. The benefits and costs of fire protection are defined below.

\section{Direct Fire Losses}

\section{Uncertain Benefits and Costs}

Property Owner Cost. When a fire occurs, the property owner incurs a financial loss from property damage that is equal in amount to the insurance deductible, or if self-insured, to the entire amount of the damage.

Insurance Industry Cost. When a fire occurs, the property owner's insurance company, if any, incurs a financial loss from property damage that equals the amount of the damage award, less the deductible.

\section{Indirect Fire Losses-Business Disruption: Profits}

Property Owner Cost. When a fire occurs, a commercial/industrial property owner (or tenant) incurs a financial loss from business disruption that is equal in amount to the business interruption insurance deductible, if insured for such a loss. If self-insured, the financial loss equals the entire financial loss from business disruption. In the extreme, business disruption is permanent, meaning bankruptcy.

Local Community Cost and Benefit. As a result of a commercial/industrial fire, suppliers and customers of the fire-hit business may lose profits. Most of these secondary losses occur in the local community and may be offset by profit gains for another. Another reason for a profit gain by other local communities is that competitors of the fire-hit firm may make up for the loss of productive capacity by using their excess capacity such that national production, and thus profit, does not change.

Insurance Industry Cost. When a fire occurs, the commercial/industrial property owner's (or tenant's) business interruption insurance company, if any, incurs a financial loss from business disruption that is equal in amount to the financial loss award from business disruption, less the deductible.

\section{Indirect Fire Losses-Business Disruption: Employment}

Local Community Cost. As a result of a commercial/industrial fire, the fire-hit business, its suppliers, and its customers may suffer employment losses due to the loss of productive capacity 
Table 1. Fire Protection Benefits and Costs by Stakeholder ${ }^{a}$

\begin{tabular}{|c|c|c|c|c|c|c|c|c|c|c|}
\hline \multirow[b]{3}{*}{ Stakeholder } & \multicolumn{5}{|c|}{ Uncertain Benefits and Costs } & \multicolumn{5}{|c|}{ Certain Benefits and Costs } \\
\hline & \multirow[b]{2}{*}{ Direct Fire Losses } & \multicolumn{2}{|c|}{$\begin{array}{c}\text { Indirect Fir } \\
\text { Business Disruption }\end{array}$} & \multicolumn{2}{|c|}{$\begin{array}{l}\text { Losses } \\
\text { Death \& Injury }\end{array}$} & \multicolumn{2}{|c|}{ Fire Protection } & \multirow[b]{2}{*}{$\begin{array}{l}\text { Insurance } \\
\text { Premiums }\end{array}$} & \multirow[b]{2}{*}{$\begin{array}{c}\text { Fire } \\
\text { Services }\end{array}$} & \multirow[b]{2}{*}{$\begin{array}{l}\text { Codes \& } \\
\text { Standards }\end{array}$} \\
\hline & & Profits & Employment & Income & Distress & Active & Passive & & & \\
\hline $\begin{array}{l}\text { Property } \\
\text { Owner }\end{array}$ & $\mathrm{C}$ & $\mathrm{C}$ & & $\mathrm{C}$ & $\mathrm{C}$ & $\mathrm{B}, \mathrm{C}$ & $\mathrm{B}, \mathrm{C}$ & $\mathrm{C}$ & C & $\mathrm{B}, \mathrm{C}$ \\
\hline $\begin{array}{l}\text { Local } \\
\text { Community }\end{array}$ & & $\mathrm{B}, \mathrm{C}$ & $\mathrm{B}, \mathrm{C}$ & $\mathrm{C}$ & $\mathrm{C}$ & B & B & & $\mathrm{C}$ & $\mathrm{C}$ \\
\hline $\begin{array}{l}\text { Insurance } \\
\text { Industry }\end{array}$ & C & $\mathrm{C}$ & & $\mathrm{C}$ & $\mathrm{C}$ & $\mathrm{B}, \mathrm{C}$ & $\mathrm{B}, \mathrm{C}$ & B & & B \\
\hline $\begin{array}{l}\text { Fire Protection } \\
\text { Device Mfr. }\end{array}$ & & & & $\mathrm{C}$ & $\mathrm{C}$ & B & B & & & $\mathrm{C}$ \\
\hline $\begin{array}{l}\text { Device } \\
\text { Testing Labs }\end{array}$ & & & & $\mathrm{C}$ & $\mathrm{C}$ & B & B & & & \\
\hline Nation & & & & & & B & B & & B & $\mathrm{B}, \mathrm{C}$ \\
\hline
\end{tabular}

${ }^{a}$ A stakeholder's economic interest in a fire protection benefit or cost is denoted by a "B," for a benefit, or "C," for a cost 
at the fire-hit business. Most of these employment losses occur in the local community and may be offset by employment gains for another.

\section{Indirect Fire Losses-Death and Injury: Income}

Property Owner, Device Manufacturer, and Testing Lab Costs. Deaths and injuries from a commercial/industrial fire can lead to profit losses for the property owner/tenant, fire protection device manufacturer, and device testing laboratory in the form of lawsuits brought to compensate for income losses of fire victims.

Local Community Cost. Deaths and injuries from a commercial/industrial fire result in income losses for the victims and their families, who are citizens of the local community. Income losses due to an injury can be from disruption in employment and from health insurance deductibles. Income losses due to a death are from loss of employment, less life insurance payout. Income losses may be offset in part or full by lawsuit winnings net of legal costs.

Insurance Industry Cost. Deaths and injuries from a commercial/industrial fire lead to life, health, and business insurance payouts to compensate for loss of income, medical bills, and legal costs.

\section{Indirect Fire Losses-Death and Injury: Distress}

Property Owner, Device Manufacturer, and Testing Lab Costs. Deaths and injuries from a commercial/industrial fire can lead to profit losses for the property owner/tenant, fire protection device manufacturer, and device testing laboratory in the form of lawsuits brought to compensate for the distress of fire victims and their families, and in the form of goodwill losses. Note that at the national level, goodwill losses are offset in part by competing firms taking advantage of a goodwill loss by increasing their share of the market.

Local Community Cost. Deaths and injuries from a commercial/industrial fire result in distress for the victims and their families, who are citizens of the local community. Distress may be offset in part or full by lawsuit winnings net of legal costs.

Insurance Industry Cost. Deaths and injuries from a commercial/industrial fire may lead to business insurance company costs from lawsuit payouts to compensate for distress.

\section{Active and Passive Fire Protection}

\section{Certain Benefits and Costs}

Property Owner Benefit and Cost. Property owners incur the life-cycle costs of active and passive fire protection, including purchase, installation, maintenance, and operating costs (e.g., water charges). Benefits include reductions in property loss, in insurance premiums, and in private fire service costs, as well as tax allowances. Tax allowances include ignoring the added property value with additional fire protection, and crediting a percent of purchase and installation costs to Federal income taxes.

Local Community Benefit. The local community saves on fire service costs as a result of active and passive fire protection. Note that this benefit may transfer to the property owner through tax allowances for fire protection. 
Insurance Industry Benefit and Cost. Insurance premiums consist of a risk portion and a profit portion. The insurance industry loses the profit portion of insurance premium reductions given property owners based on their lower risk exposure with active and passive fire protection. On the other hand, the lower risk exposure transferred to the insurance industry reduces the variability of insurance payouts, resulting in greater profit rates for insurance companies. Thus, while insurance revenues may go down, profits may go up.

Device Manufacturer Benefit. Manufacturers of active and passive fire protection technologies earn profit from their sale.

Testing Lab Benefit. Device testing labs earn profit from testing fire safety systems.

National Benefit. The increase in public safety from active and passive fire protection measures is a societal benefit.

\section{Insurance}

Property Owner Cost. In exchange for the transfer of their exposure to the risk of fire loss, property owners pay insurance premiums regularly.

Insurance Industry Benefit. The insurance stakeholder receives regular insurance premiums from the property owner in exchange for accepting their exposure to the risk of fire losses. The premium consists of a risk portion and a profit portion.

\section{Fire Services}

Property Owner Cost. Property owners pay property taxes to support local fire services and directly fund private fire services.

Local Community Cost. The local community and its citizens provide funds to the local fire service through property taxes and fundraising drives.

National Benefit. The increase in public safety from local and private fire services is a societal benefit.

\section{Codes and Standards}

Property Owner Benefit and Cost. The property owner benefits from codes and standards through reduced death, injury, and property loss; and pays for compliance costs net of active and passive fire protection costs.

Local Community Cost. The local community pays for codes and standards through code development and enforcement. 
Insurance Industry Benefit. Codes and standards provide information to help the insurance industry better manage its risk exposure, a benefit.

Device Manufacturer Cost. The device manufacturer pays for codes and standards through compliance costs.

National Benefit and Cost. The Nation enjoys a societal benefit, increased public safety, in exchange for its code and standard development costs.

\subsection{Fire Dynamics Simulator}

Having defined the benefits, costs, and stakeholders of the fire protection industry as a whole, the benefits and costs specifically attributable to the FDS research program may be identified. An important simplifying assumption is that the chief benefit of FDS is information. That is, FDS provides decision makers with better and more complete information with which to make cost-effective fire protection decisions. It is assumed FDS does not change the probability of or likely property loss from a fire. Its primary impact is one of cost reduction through better information. In other words, a key assumption is that public safety, and thus uncertain costs, is held constant while the certain costs of fire protection are reduced. ${ }^{5}$

Table 2 identifies the certain benefits and costs of FDS by stakeholder group. In this table, a stakeholder's financial interest (benefit or cost) is denoted by a " $\mathrm{B}_{\mathrm{FDS}}$ " for a benefit or " $\mathrm{C}_{\mathrm{FDS}}$ " for a cost. Those benefits and costs affected by the FDS application to the sprinkler/draft curtain/roof vent issue are further identified with an asterisk (" $\mathrm{B}_{\mathrm{FDS}}$ ”" for a benefit and " $\mathrm{C}_{\mathrm{FDS}}$ *" for a cost).

\section{Active Fire Protection}

Property Owner Benefit and Cost. FDS allows for more cost-effective fire protection system design through better fire scenario prediction accuracy. In other words, FDS provides more precise risk estimates, so system designers need not use the overly conservative risk estimates of the past that led to higher system costs. This FDS benefit is relevant to the sprinkler/draft curtain/roof vent application because the FDS application tested the utility of draft curtains in sprinklered warehouses. Besides the potential for savings in draft curtain costs, further savings were at stake because draft curtains limit flexibility in warehouse floor layout. Storage racks are not permitted beneath draft curtains. Eliminating draft curtains from sprinklered warehouses would thus permit greater efficiency in warehouse floor layout.

Property owners often finance the full-scale tests that may yield the scientific proof required to eliminate overly conservative fire protection requirements. In the case of the sprinkler/draft curtain/roof vent application, an industry consortium led by the National Fire Protection Research Foundation and including the American Architectural Manufacturers Association, Colt Industries, Ford Motor Company, General Motors, Home Depot, Industrial Risk Insurers (now

\footnotetext{
${ }^{5}$ Note that for the sprinkler/draft curtain/roof vent application of FDS, some tests have shown that uncertain costs may actually rise with draft curtains in sprinklered facilities because the presence of the curtains causes more sprinklers to activate in a fire, causing more sprinkler damage to property.
} 
GE Capital), National Fire Protection Association, three member companies of the National Fire Sprinkler Association (Central Sprinkler Company, Grinnell Corporation, and Viking Corporation) financed full-scale tests.

Table 2. FDS Benefits and Costs by Stakeholder ${ }^{\mathrm{a}}$

\begin{tabular}{|c|c|c|c|c|c|}
\hline \multirow[b]{2}{*}{ Stakeholder } & \multicolumn{5}{|c|}{ Certain Benefits and Costs } \\
\hline & $\begin{array}{l}\text { Fire Prote } \\
\text { Active }\end{array}$ & $\begin{array}{l}\text { ction } \\
\text { Passive }\end{array}$ & $\begin{array}{l}\text { Insurance } \\
\text { Premiums }\end{array}$ & $\begin{array}{c}\text { Fire } \\
\text { Services }\end{array}$ & $\begin{array}{l}\text { Codes \& } \\
\text { Standards }\end{array}$ \\
\hline $\begin{array}{l}\text { Property } \\
\text { Owner }\end{array}$ & $\mathrm{B}_{\mathrm{FDS} *}, \mathrm{C}_{\mathrm{FDS} *}$ & & & & $\mathrm{~B}_{\mathrm{FDS}} *$ \\
\hline $\begin{array}{l}\text { Local } \\
\text { Community }\end{array}$ & & & & & $\mathrm{C}_{\mathrm{FDS}}$ \\
\hline $\begin{array}{l}\text { Insurance } \\
\text { Industry }\end{array}$ & & & $\mathrm{B}_{\mathrm{FDS} *}$ & & \\
\hline $\begin{array}{l}\text { Fire Protection } \\
\text { Device Mfr. }\end{array}$ & $\mathrm{B}_{\mathrm{FDS}}, \mathrm{C}_{\mathrm{FDS}} *$ & & & & $\mathrm{~B}_{\mathrm{FDS}}$ \\
\hline $\begin{array}{l}\text { Device } \\
\text { Testing Labs }\end{array}$ & $\mathrm{B}_{\mathrm{FDS}}, \mathrm{C}_{\mathrm{FDS}}$ & & & & \\
\hline Nation & & & & & $\begin{array}{c}\mathrm{B}_{\mathrm{FDS}} \\
\mathrm{C}_{\mathrm{FDS} *} \\
\end{array}$ \\
\hline
\end{tabular}

a Potential FDS research benefits and costs are denoted by the subscript "FDS.” Those benefits and costs relevant to the FDS sprinkler/draft curtain/roof vent application are further denoted by as asterisk following the "FDS" subscript (FDS*). Table 1 fire protection benefits and costs are given in gray shading for reference.

Device Manufacturer Benefit and Cost. FDS can potentially lower manufacturer research and development costs by:

1. Simplifying and speeding up product development. FDS can reduce the number of expensive full-scale tests needed from testing laboratories by simulating these experiments, facilitating product designs with a greater chance of passing full-scale tests earlier in the testing series. Furthermore, since laboratory testing takes time to design and conduct, reducing their number will shorten the time-to-market for new products, a key factor in product profitability. This benefit does not apply to the FDS application studied here because a new product was not at stake.

2. Enabling more effective and reliable products. Fed by better technical information from FDS, designers may have more insight with which to design better fire protection technologies. In the long run, this may reduce the risk of fire and its associated uncertain costs. In the short run, this will lead to increased profit from sales (including foreign sales), as well as fewer 
lawsuits from malfunctioning devices. Note that reduced sales of selected product lines, as in the sprinkler/draft curtain/roof vent application, must be accounted for in measuring sales changes. The FDS application had the potential to reduce installations of draft curtains.

Testing Lab Benefit and Cost. FDS has the potential to reduce the number of tests required in a typical testing series (see Device Manufacturer Benefit above), thereby reducing testing lab profit. On the other hand, the number of testing series demanded may increase with their greater affordability, thereby increasing testing lab profit. In the context of the sprinkler/draft curtain/roof vent study, a single series of five full-scale tests was conducted, rendering these offsetting changes in lab profit inconsequential.

Insurance Industry Benefit. FDS can potentially provide better information to insurance companies with which to assess risk and set competitive insurance rates, leading to increased sales. This is especially important now with strong foreign competition. The FDS application indirectly had this impact on the insurance industry.

\section{Codes and Standards}

Property Owner Benefit. FDS potentially generates detailed and reliable information that can substitute for and validate full-scale testing results, so that property owners may convince code officials of the fire safety of a more cost-effective design. The sprinkler/draft curtain/roof vent application had the potential to remove costly draft curtain requirements from the Uniform Fire Code.

Local Community Cost. Since FDS stimulates performance-based solutions, there will be a greater variety of designs for the local community to approve. This potential cost is irrelevant in the context of the sprinkler/draft curtain/roof vent application because the issue was with the prescriptive Uniform Fire Code.

Device Manufacturer Benefit. FDS potentially lowers manufacturer research and development costs by providing more detailed and reliable information with which manufacturers can document the fire safety of a new product, thereby simplifying the product approval process. This potential FDS benefit does not apply in the context of the sprinkler/draft curtain/roof vent application because it was removal of a fire protection device requirement that was at stake.

National Benefit and Cost. FDS provides more detailed and reliable information with which to develop codes and standards, potentially leading to increased fire safety. Since the level of fire safety is assumed unchanged in the context of the FDS application studied here, this benefit is irrelevant. Another FDS benefit is its potential role in advancing the development of performance-based fire safety codes and standards. FDS removes an obstacle to performancebased codes by offering a sound assessment technique to estimate losses from fires in individual buildings. The authorities need such estimates to relax the requirements specified in prescriptive codes. While the sprinkler/draft curtain/roof vent application is conceivably an important first step in demonstrating FDS' potential for accelerating performance-based solutions, its actual benefit was limited to changing the prescriptive code.

BFRL's FDS application development costs are costs incurred by the Nation. 


\section{Data and Assumptions}

The focus of this economic impact study is the FDS application to fire protection requirements in warehouse facilities. The Uniform Fire Code (UFC), which serves as a model code for about one-third of the Nation, required three fire protection devices in warehouses: sprinklers, draft curtains, and roof vents. Property owners thought these requirements as outdated, overly conservative, and costly. They originated in the late 1960's when taller warehouses were being built to accommodate high pile stock. This presented a fire protection challenge that sprinkler technology at the time could not meet alone. It was thought that roof vents and draft curtains could effectively pocket heat and smoke and lead to increased sprinkler effectiveness. As sprinkler technology improved over the succeeding decades, however, property owners and sprinkler manufacturers questioned the need for draft curtains in sprinklered warehouses.

TVA, Incorporated, a highly regarded fire protection engineering firm with offices throughout the United States, had been studying the issue of draft curtain utility on behalf of property owners for decades. TVA, Inc. had conducted full-scale tests with Factory Mutual (FM), a testing laboratory, that questioned the utility of draft curtain requirements in sprinklered warehouse facilities. After the FM tests, and at the request of large warehouse property owners including General Motors, Ford, and Home Depot, the NIST/BFRL Fire Safety Engineering Division modeled and simulated the full-scale tests with their FDS software. The FM testing results provided key data enabling the development of a practical FDS application to the science of sprinkler, draft curtain, and roof vent interactions. These developments encouraged the large warehouse property owners to finance, through the National Fire Protection Research Foundation (NFPRF), five full-scale tests conducted at Underwriters Laboratories and guided by FDS simulations. With a limited budget for full-scale testing, the idea was to run FDS simulations before each new full-scale test to help design the test to return the most information possible. The simulation/testing approach bore fruit. It yielded enough scientific evidence to convince code officials to remove draft curtain requirements. In 2000, UFC removed draft curtain requirements for sprinklered warehouse facilities.

To estimate the economic impact to the Nation of the UFC change, and BFRL's contribution to the impact, the benefits and costs identified in table 2 as being relevant to the FDS application are quantified to the extent possible. The relevant benefits and costs are organized by stakeholder and estimated below. Note that measures of economic impact are developed in Chapter 4 by evaluating these benefits and costs over a period of 25 years beginning in 1996, when NIST began incurring development costs for the FDS application, and ending in 2020, for a study period of 25 years. The study period is set at 25 years for consistency with other BFRL economic impact studies.

The base year, or the year for which time-equivalent values for all costs and savings are computed, is 2000. While the base year may be set at any year in the study period, the year 2000 


\section{Figure 1. Total Warehouse Floorspace by Year of Construction}

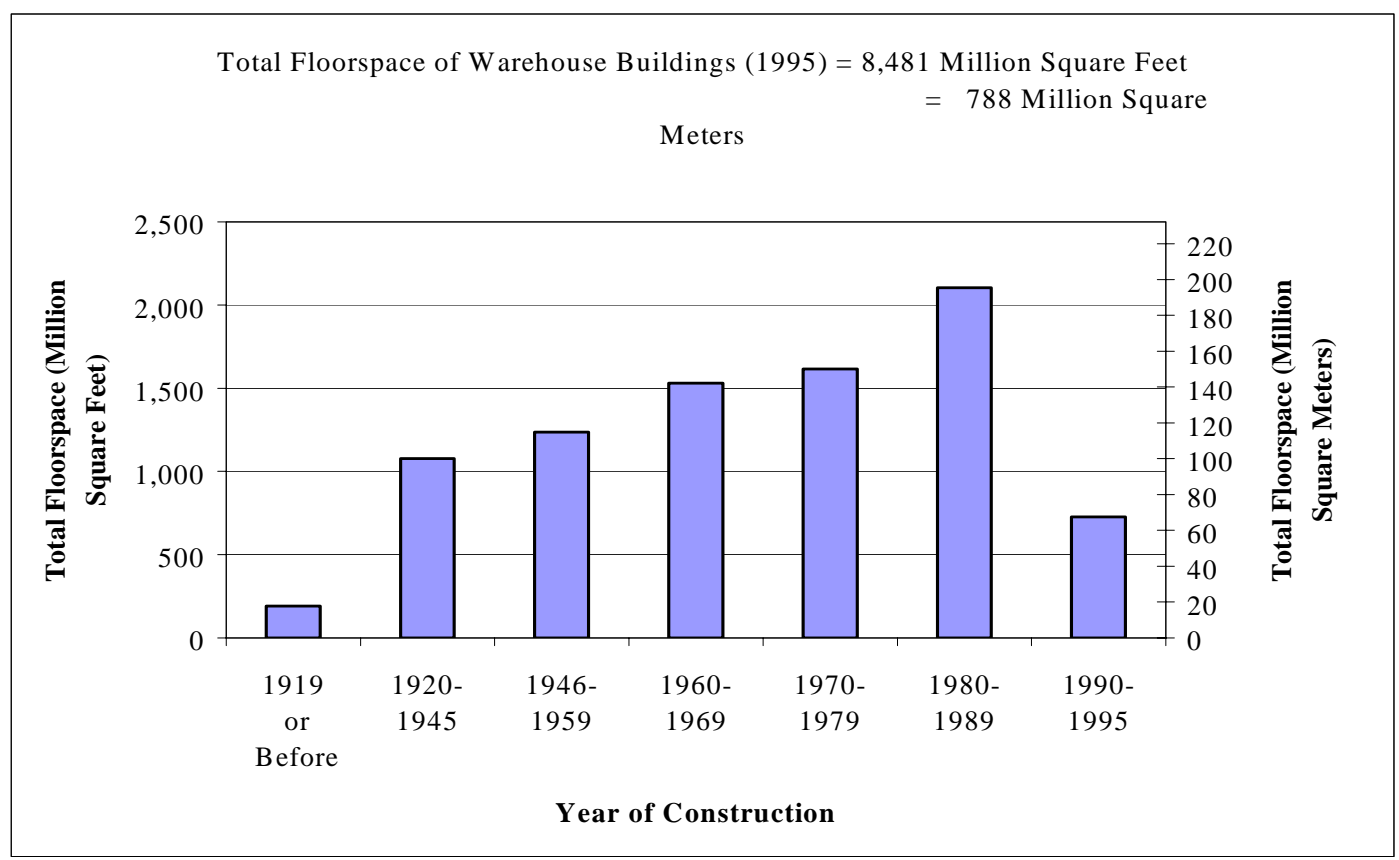

Source: U.S. Department of Energy, Commercial Buildings Energy Consumption Survey.

is selected because results are more readily interpreted by readers when they are expressed in today's dollars.

\section{Property Owner}

The UFC code change applies to newly constructed, sprinklered warehouse facilities under certain storage conditions. Figure 1 displays the latest available data for U.S. warehouse construction showing total warehouse floorspace as of 1995 by year of construction. Note that the rightmost bar indicates that 67.6 million square meters (727.5 million square feet) of the 1995 stock was built over the five-year period 1990-1995. Extrapolating 1990-1995 figures through the year 2020 will likely yield a conservative estimate for new warehouse floorspace given the weakness of the commercial real estate market in the United States in the early '90s. Based on these data and assumptions, then, new warehouse floorspace is assumed to average 13.5 million square meters (727.5/5, or 145.5 million square feet) annually over the study period.

Several considerations limit the floorspace to which the UFC change applies. Estimates of the size of these limitations are provided by William Tomes, Principal of TVA, Inc. ${ }^{6}$ First, the UFC change applies only to warehouses that store high pile stock, consisting of any stock over 3.7 meters (12 feet) high, or any Group A plastic stock over 1.5 meters (5 feet) high. Between $95 \%$ and $99 \%$ of new warehouse square footage meets these rather liberal storage requirements. For a conservative benefit estimate, the $95 \%$ lower bound for applicable warehouse square footage is used. Second, the UFC model code covers occupancies in only one-third to one-half of the country. A figure of one-third for eligible warehouse floorspace will be used, again for a

\footnotetext{
${ }^{6}$ Interviews with William Tomes, Principal of TVA, Inc., Atlanta, GA, 9/27/00 and 10/2/00.
} 
conservative benefit estimate. Third, in areas covered by the UFC, local jurisdictions may require draft curtains in sprinklered warehouse occupancies despite UFC requirements, or new warehouses may be built with draft curtains for other reasons. These contingencies reduce by an additional $5 \%$ the warehouse floorspace actually affected by the UFC change. Finally, another 5 $\%$ of new warehouse square footage is not sprinklered, rendering this space ineligible to take advantage of the code change.

Warehouse property owners supported removal of the UFC requirement for draft curtains for two major reasons: curtain cost and floorspace flexibility. Regarding cost, the removal of draft curtain requirements led to significant cost savings for property owners. Draft curtains are rather unique fire protection devices; there are no draft curtain manufacturers per se. Rather, draft curtains are individually "manufactured" by contractors who build, assemble, and install these devices at the construction site using sheet metal. For this reason, draft curtains are not "products" for which national average costs are reported in construction cost manuals such as those published by R.S. Means, Inc. However, TVA, Inc. has conducted an informal study of draft curtain costs. According to TVA's William Tomes, draft curtains cost between $\$ 4.31$ and $\$ 6.46$ per square meter of floorspace $\left(\$ 0.40-\$ 0.60\right.$ per $\left.\mathrm{ft}^{2}\right)$, depending on warehouse size and including materials, labor, and overhead and profit. However, there are significant hidden costs associated with installing draft curtains. All ceiling utilities, including lighting, duct work, and sprinkler systems, must be installed by punching holes through the obstruction created by draft curtains, significantly adding to their installed costs. These complications can more than double or triple the "real" cost of draft curtains, with estimates reaching $\$ 14.64$ per square meter ( $\$ 1.36$ per $\left.\mathrm{ft}^{2}\right) .{ }^{7}$ For the baseline economic impact analysis presented in the next chapter, a simple average of the lowest cited cost for direct draft curtain installation $\left(\$ 4.31 / \mathrm{m}^{2}\right.$, or $\left.\$ 0.40 / \mathrm{ft}^{2}\right)$ and the highest cited cost including hidden costs $\left(\$ 14.64 / \mathrm{m}^{2}\right.$, or $\left.\$ 1.36 / \mathrm{ft}^{2}\right)$ will be used, yielding an estimate of $\$ 9.48$ per square meter $\left(\$ 0.88 / \mathrm{ft}^{2}\right.$ ) for draft curtain installation. ${ }^{8}$ Draft curtain costs are a key vairable in the economic impact analysis and will be the subject of sensitivity analysis in Chapter 5.

The other important benefit to property owners afforded by the UFC change is increased flexibility in warehouse floor layout. Storage racks are not permitted beneath draft curtains. Eliminating draft curtains thus permits greater efficiency in warehouse floor layout, a potentially significant benefit for which there is no reliable quantitative data. Increased flexibility in floor layout will be treated as an important qualitative benefit in the context of this economic study.

Offsetting the benefits to property owners of the UFC change is their expenditure for the smalland full-scale testing that complemented the FDS simulations. The NFPRF-led industry consortium contributed approximately $\$ 450,000$ in 1997 dollars (or $\$ 478,598$ in 2000 dollars) for the testing series. These costs, which occured in 1997, are deducted from benefits in the economic impact calculation.

\section{Insurance Industry}

\footnotetext{
${ }^{7}$ Interviews with William Tomes, Principal of TVA, Inc., Atlanta, GA, 9/27/00 and 10/2/00.

${ }^{8}$ Note that the simple average is used to estimate the expected value of the distribution of draft curtain costs in the absence of reliable data on the nature of the probability distribution of draft curtain costs.
} 
GE Industrial Risk Insurers (IRI), one of the largest warehouse insurers in the world, had for years recommended draft curtains and roof vents in sprinklered warehouses. According to IRI's Research Director Kenneth Linder, ${ }^{9}$ IRI recognized that advances in sprinkler technology over the years had reduced the need for draft curtains, so IRI did not press the issue of draft curtains and roof vents in these occupancies. Yet IRI was reluctant to entirely remove draft curtain recommendations without compelling scientific evidence to back up the position. The full-scale tests guided by the FDS application and undertaken by the NFPRF-led industry consortium provided the evidence they needed. IRI no longer routinely recommends draft curtains in warehouses. The FDS application helped provide an insurance company, in this case the single major warehouse insurer still recommending draft curtains, with better information with which to assess risk and set company policy. This is an important impact because in the competitive insurance industry, technical information that supports policy changes that in turn lead to significant property owner cost savings can increase an insurance company's competitiveness. And in today's global insurance market with stiff foreign competition, any competitive advantage can lead to increased sales. While data are not available to quantify this benefit of the FDS application, it is treated as an important qualitative benefit in the economic impact assessment.

\section{Device Manufacturer}

In the case of draft curtains, the "manufacturer" is the contractor who builds, assembles, and installs the devices on site. In a national context, the profit portion of installed draft curtain costs should be treated as a cost of the UFC change because removing draft curtain requirements has the disadvantage of lowering contractor profit. Contractor profit rates in the United States range from $5 \%$ to $15 \% .^{10}$ Deducting the average profit rate of $10 \%$ from baseline draft curtain installation cost savings of $\$ 9.48$ per square meter $\left(\$ 0.88 / \mathrm{ft}^{2}\right)$ yields a net savings figure of $\$ 8.50$ per square meter $\left(\$ 0.79 / \mathrm{ft}^{2}\right)$ for the baseline economic impact analysis. Contractor profit rates, a key variable in the economic impact analysis, will be the subject of sensitivity analysis in Chapter 5.

\section{Nation}

The NIST Building and Fire Research Laboratory (BFRL) funded the research required to apply the FDS model to the sprinkler/draft curtain/roof vent issue. These costs occurred from fiscal years (FY) 1996 through 2000 and include research related to further FDS model development, a software user interface, radiation transport, contract research performed by Northwestern University, as well as work done in FY 1999 and FY 2000 to develop a version of the improved FDS tool suitable for public release. In current dollars, these BFRL investment costs total \$360,000 in FY96, \$688,000 in FY97, \$772,000 in FY98, \$755,000 in FY99, and \$547,500 in FY00. Since these research investment costs are incurred on a fiscal year basis while all other annual data for this case study are reported on a calendar year basis, fiscal year costs are converted to calendar year costs. Research investment costs are primarily staff-related costs incurred throughout the fiscal year, so the conversion is accomplished by simply allocating $25 \%$ of fiscal year costs to the previous calendar year and $75 \%$ to the current calendar year. ${ }^{11}$

\footnotetext{
${ }^{9}$ Interview with Kenneth Linder, Research Director for GE Industrial Risk Insurers, Hartford, CT, 10/5/00.

${ }^{10}$ R.S. Means Company, Inc., 1999. 2000 Building Construction Cost Data, CSI Subdivision 01310, on CD-ROM of Means 2000 CostWorks. Kingston, MA.

${ }^{11}$ Investment costs for FY96 are allocated entirely to calendar year 1996 because BFRL staff did not begin work on
} 


\section{BFRL Contribution to Savings}

Interviews with a variety of fire protection stakeholders helped establish the contribution made by BFRL to the UFC change. Stakeholders representing the fire research community, fire code officials, property owners, and the insurance industry all agreed that the five full-scale tests conducted at Underwriter's Laboratories (UL) in 1997 and designed with NIST FDS simulations provided the scientific evidence compelling UFC code officials and the IRI to remove draft curtain requirements from sprinklered warehouses. ${ }^{12}$ While additional requirements are regularly added to fire codes, it is rare for any code requirement to be removed. The UFC change, therefore, was both a rare and significant accomplishment. And according to Rick Mulhaupt, President of the National Fire Protection Research Foundation, ${ }^{13}$

"The Uniform Fire Code would not have changed without NIST. I could not see removal of draft curtains on the horizon. NIST took the whole debate several steps beyond where it had been before."

According to Dave Nuss, NFPA Regional Manager and staffer for the draft curtain/smoke and heat vent-related code work for the Western Fire Chiefs Association (developers of the UFC), ${ }^{14}$

"The FDS results provided the compelling testimony at the code hearings that gave the fire service the confidence to approve the proposed code change (removing draft curtain requirements from sprinklered warehouses)."

A contrary opinion was voiced by Hughes Associates, a fire protection engineering firm representing roof vent manufacturers. Roof vent manufacturers are threatened by UFC removal of draft curtain requirements, anticipating removal of roof vent requirements as the logical next step. According to Hughes' Craig Beyler, while he is a big supporter of the FDS model and software and has no doubt the NIST report documenting the FDS simulations and the five fullscale tests was influential, he questions the extent of the contribution made by the FDS simulations. Rather, he credits the UFC change to preconceptions of key decisionmakers going in to the full-scale tests. According to Beyler, decisionmakers went into the UL testing series with knowledge of the results of the earlier full-scale tests conducted by TVA, Inc. at FM indicating potential problems with draft curtains. They were predisposed, then, to confirm their expectations by interpreting new full-scale tests similarly if its results were close to those from the earlier tests. It was the full-scale tests, not the FDS simulations, that motivated the UFC code change. ${ }^{15}$

\footnotetext{
the new project until after January 1, 1996.

${ }^{12}$ Interviews with Rick Mulhaupt, President, National Fire Protection Research Foundation, Quincy, MA, 9/29/00; William Tomes, Principal, TVA, Incorporated, Atlanta, GA, 9/27/00; Kenneth Linder, Research Director, GE Industrial Risk Insurers, Hartford, CT, 10/5/00; Todd Schumann, GE Industrial Risk Insurers, Chicago, IL, 10/9/00; Dave Nuss, NFPA Regional Manager, Denver, CO, 12/19/01; David Evans, Chief, Fire Safety Engineering Division, NIST, Gaithersburg, MD, 6/14/99 and 9/14/00; Kevin McGrattan, FDS Project Leader, NIST, Gaithersburg, MD, 10/4/00 and 10/10/00.

${ }^{13}$ Mulhaupt interview, 9/29/00.

14 Nuss interview, 12/19/01.

${ }^{15}$ Craig Beyler interview, Hughes Associates, Baltimore, MD, 10/2/00.
} 
The Hughes argument is debatable. As noted above, it is rare for a code requirement to be removed or for an insurance company to change its position. According to NFPRF, a neutral party without a bias toward either property owners or vent manufacturers, the draft curtain debate for both code officials and IRI hinged on technical issues, which only compelling fullscale test results could resolve. Moreover, the FDS simulations played the key role of methodically designing and analyzing those tests. The scientific research community widely shares the belief that simulation plays a major role in experiment design, offering the ability to target the most critical parameters for further full-scale testing, thus making more effective use of the full-scale tests. Simulation studies can also substitute for some tests by permitting extrapolation of conditions not actually observed. Several hundred different combinations of variables such as room configuration, load of combustible materials, and air flow can be simulated in a short period of computer time, reducing the number of required full-scale tests to a carefully selected set of critical ones. The NFPRF-led industry consortium could only afford to fund five full-scale tests, so the demonstrated ability of the FDS simulations to efficiently design a limited number of tests to yield compelling scientific evidence was critical to the successful removal of draft curtain requirements from sprinklered warehouses. The FDS simulations carefully designed and analyzed the full-scale tests to return the critical information within the limited budget. Without the FDS simulations, an infeasible number of full-scale tests would most likely have been required.

Based on the above, this economic impact study assumes the FDS simulations were critical to the code change. The strong endorsement given by the President of the National Fire Protection Research Foundation, a highly respected neutral party without a bias toward either property owners or vent manufacturers, that the UFC code change would not have occurred any time in the foreseeable future without NIST, supports the assumption that, as an upper bound, NIST/BFRL contributed $100 \%$ to the resulting savings in draft curtain costs. The counterargument by Hughes supports the lower-bound assumption that NIST/BFRL contributed $50 \%$ to the savings. 


\section{Baseline Analysis of Economic Impacts}

In this chapter, the baseline data developed in Chapter 3 are expressed as streams of benefit and cost flows that will provide direct input into calculating economic impact measures indicating the payoff on BFRL's research investment dollars. For consistency and comparability, the same economic impact measures and analysis parameters are used as in the four earlier impact studies prepared by BFRL. ${ }^{16}$ As these impact measures and analysis parameters are extensively documented in the earlier BFRL reports and are widely accepted as methodologically appropriate and empirically sound, they are not explained in great detail here. The key message is that economic impact is expressed as present value net savings, savings-to-investment ratio, and adjusted internal rate of return as defined by ASTM standard practices. ${ }^{17}$ Present value net savings is a magnitude measure, showing the dollar value to the public net of FDS application investments. The savings-to-investment ratio is a multiplier; it shows how many dollars the public receives for each public dollar spent. The adjusted internal rate of return shows the annual return on public dollars spent on development of the FDS application. The period over which costs and savings are measured begins in 1996, when BFRL began investing in the FDS application, and ends in 2020, for a study period of 25 years as in the earlier BFRL studies. The discount rate for converting future costs to their equivalent present value is a real rate of $7 \%$, as in the earlier BFRL studies and as required by OMB Circular A-94 for all benefit-cost analyses of public investments that provide benefits or costs to the general public. ${ }^{18}$ Finally, since draft curtain costs and profit rates vary significantly and are key to the economic analysis, they will be the subject of sensitivity analysis in Chapter 5. For a complete description of benefit-cost analysis and its evaluation methods, including their algebraic representations, refer to Chapters 2 and 3 of the 1996 BFRL study. ${ }^{19}$

Table 3 translates the warehouse floorspace data itemized in the previous chapter into total warehouse floorspace taking advantage of the UFC change. Note in column 5 the final result of 3.9 million square meters per year (41.5 million square feet per year). This is a conservative estimate for two reasons. First, in all cases, the lower bound for applicable floorspace is used. Second, due to data limitations, an assumption is made that all restrictions on applicable floorspace-storage conditions, UFC coverage, local code requirements, and sprinklering-are mutually exclusive. For example, floorspace that does not meet storage requirements is assumed to satisfy the remaining conditions for UFC coverage, local codes, and sprinklering. If that same floorspace actually satisfies any of the other conditions, it should not be removed again for each additional condition it satisfies, as is done in table 3. Realistically, floorspace could easily meet two or more conditions. Thus, table 3 gives a conservative estimate of applicable floorspace.

\footnotetext{
${ }^{16}$ Chapman, R. E. 2000; Chapman, R. E. 1999; and Chapman, R. E., and S. K. Fuller. 1996.

${ }^{17}$ American Society for Testing and Materials. Fourth Edition, 1999. ASTM Standards on Building Economics. West Conshohocken, PA: American Society for Testing and Materials.

${ }^{18}$ Executive Office of the President. 1992. OMB Circular A-94. Washington, DC: Office of Management and Budget

${ }^{19}$ Chapman, R. E. and S. K. Fuller. 1996.
} 


\section{Table 3. Warehouse Floorspace Affected by Uniform Fire Code Change in Millions of Square Meters per Year (million $\mathrm{ft}^{2} / \mathrm{yr}$ )}

\begin{tabular}{|c|c|c|c|c|}
\hline $\begin{array}{c}\text { New } \\
\text { Warehouse } \\
\text { Floorspace } \\
(1)\end{array}$ & $\begin{array}{c}\text { Meets Storage } \\
\text { Requirements }\end{array}$ & $\begin{array}{c}\text { Covered by } \\
\text { Uniform Fire } \\
\text { Code } \\
(2)=(1) * 0.95\end{array}$ & $\begin{array}{c}\text { Local Code } \\
\text { without } \\
\text { Curtains } \\
(4)=(2) * 0.33\end{array}$ & Sprinklered \\
\hline 13.5 & 12.8 & 4.3 & 4.1 & $\mathbf{3 . 9}$ \\
$(145.5)$ & $(138.2)$ & $(46.0)$ & $(43.7)$ & $\mathbf{( 4 1 . 5 )}$ \\
\hline
\end{tabular}

Table 4 illustrates the derivation of the present value net savings measure. Assuming all savings are attributable to NIST/BFRL, the net draft curtain cost savings figure developed in Chapter 3 is applied to the applicable floorspace figure given in table 3 , assigning the resulting total cost savings, \$32.90 million, to each year in the economic study period after the UFC change. The cost of the full-scale tests financed by the NFPRF-led industry consortium is assigned to the year in which it was incurred, 1997. Using the assumed discount rate of $7 \%$, this stream of costs and cost savings is converted to equivalent present values and summed. Since all savings are assumed attributable to BFRL, the sum, $\$ 380.8$ million, represents the Present Value Savings Attributable to BFRL for the FDS application. In table 5, the stream of BFRL research costs over the five-year period 1996-2000, expressed in year 2000 dollars, is converted to equivalent present values and summed to arrive at the Present Value of Investment Costs to BFRL.

The two summary figures derived in tables 4 and 5, Present Value Savings Attributable to BFRL and Present Value Investment Costs to BFRL, are used to develop the three summary economic impact measures given in the standardized BFRL Summary Impact Statement displayed in exhibit $1 .{ }^{20}$ Since the baseline analysis assumes that savings attributable to NIST/BFRL range from $50 \%$ to $100 \%$, a corresponding range is shown for each impact measure. The Present Value Net Savings Attributable to BFRL, PVNS, ranges from \$186.3 million to \$377.0 million, a magnitude measure showing the dollar value to the public net of FDS application investments. The Savings-to-Investment Ratio of the BFRL Contribution, SIR, ranges from 50.24 to 100.61, a multiplier showing how much the public receives for each public dollar spent on the FDS application. The Adjusted Internal Rate of Return of the BFRL Contribution, AIRR, ranges from 0.251 to 0.287 , showing the return on public dollars spent on FDS application development throughout the study period. The three measures indicate that the FDS application was a very economically worthwhile project because their values far exceed conditions for economic worth (PVNS > 0), SIR > 1, and AIRR > $7 \%$ ).

\footnotetext{
${ }^{20}$ The format for the standard BFRL Summary Impact Statement was developed and reported in Chapman, R. E., and S. K. Fuller. 1996.
} 
Table 4. Baseline Analysis: Present Value Savings Assuming All Savings Attributable to BFRL, in 2000 Dollars

\begin{tabular}{|c|c|c|c|c|c|c|}
\hline $\begin{array}{l}\text { Year } \\
(1)\end{array}$ & $\begin{array}{c}\text { Net Draft Curtain } \\
\text { Cost Savings } \\
\text { in } \$ / \mathrm{m}^{2}\left(\$ / \mathrm{ft}^{2}\right) \\
(2)\end{array}$ & $\begin{array}{c}\text { Applicable } \\
\text { Floorspace } \\
\mathrm{M} \mathrm{m}^{2}\left(\mathrm{M} \mathrm{ft}^{2}\right) \\
\text { (3) }\end{array}$ & $\begin{array}{l}\text { Total Cost } \\
\text { Savings } \\
\text { \$M } \\
(4)=(2)^{*}(3)\end{array}$ & $\begin{array}{c}\text { NFPRF Testing } \\
\text { Costs } \\
\$ M \\
(5)\end{array}$ & $\begin{array}{c}\text { Discount Factor } \\
(6)\end{array}$ & $\begin{array}{c}\text { Present Value } \\
\text { Cost Savings } \\
\$ M \\
(7)=(4)^{*}(6)\end{array}$ \\
\hline \multicolumn{7}{|l|}{1996} \\
\hline 1997 & & & & 0.479 & 1.225 & $-0.586^{\mathrm{a}}$ \\
\hline \multicolumn{7}{|l|}{1998} \\
\hline \multicolumn{7}{|l|}{1999} \\
\hline 2000 & $8.50(0.79)$ & $3.9(41.5)$ & 32.90 & & 1.000 & 32.90 \\
\hline 2001 & $8.50(0.79)$ & $3.9(41.5)$ & 32.90 & & 0.935 & 30.75 \\
\hline 2002 & $8.50(0.79)$ & $3.9(41.5)$ & 32.90 & & 0.873 & 28.73 \\
\hline 2003 & $8.50(0.79)$ & $3.9(41.5)$ & 32.90 & & 0.816 & 26.85 \\
\hline 2004 & $8.50(0.79)$ & $3.9(41.5)$ & 32.90 & & 0.763 & 25.10 \\
\hline 2005 & $8.50(0.79)$ & $3.9(41.5)$ & 32.90 & & 0.713 & 23.46 \\
\hline 2006 & $8.50(0.79)$ & $3.9(41.5)$ & 32.90 & & 0.666 & 21.92 \\
\hline 2007 & $8.50(0.79)$ & $3.9(41.5)$ & 32.90 & & 0.623 & 20.49 \\
\hline 2008 & $8.50(0.79)$ & $3.9(41.5)$ & 32.90 & & 0.582 & 19.15 \\
\hline 2009 & $8.50(0.79)$ & $3.9(41.5)$ & 32.90 & & 0.544 & 17.89 \\
\hline 2010 & $8.50(0.79)$ & $3.9(41.5)$ & 32.90 & & 0.508 & 16.72 \\
\hline 2011 & $8.50(0.79)$ & $3.9(41.5)$ & 32.90 & & 0.475 & 15.63 \\
\hline 2012 & $8.50(0.79)$ & $3.9(41.5)$ & 32.90 & & 0.444 & 14.61 \\
\hline 2013 & $8.50(0.79)$ & $3.9(41.5)$ & 32.90 & & 0.415 & 13.65 \\
\hline 2014 & $8.50(0.79)$ & $3.9(41.5)$ & 32.90 & & 0.388 & 12.76 \\
\hline 2015 & $8.50(0.79)$ & $3.9(41.5)$ & 32.90 & & 0.362 & 11.92 \\
\hline 2016 & $8.50(0.79)$ & $3.9(41.5)$ & 32.90 & & 0.339 & 11.14 \\
\hline 2017 & $8.50(0.79)$ & $3.9(41.5)$ & 32.90 & & 0.317 & 10.41 \\
\hline 2018 & $8.50(0.79)$ & $3.9(41.5)$ & 32.90 & & 0.296 & 9.73 \\
\hline 2019 & $8.50(0.79)$ & $3.9(41.5)$ & 32.90 & & 0.277 & 9.10 \\
\hline 2020 & $8.50(0.79)$ & $3.9(41.5)$ & 32.90 & & 0.258 & 8.50 \\
\hline \multicolumn{6}{|c|}{ Present Value Savings Attributable to BFRL: } & 380.8 \\
\hline
\end{tabular}

\footnotetext{
${ }^{a}$ For 1997, present value cost savings is computed by taking the negative of the product of columns (5) and (6).
} 
Table 5. Present Value Investment Costs to BFRL, in Millions of 2000 Dollars

\begin{tabular}{|c|c|c|c|}
\hline $\begin{array}{c}\text { Year } \\
(1)\end{array}$ & $\begin{array}{c}\text { BFRL } \\
\text { Investment } \\
\text { Costs } \\
(2)\end{array}$ & $\begin{array}{c}\text { Single Compound Amount } \\
\text { Discount Factor } \\
(3)\end{array}$ & $\begin{array}{c}\text { Present Value BFRL } \\
\text { Investment Costs } \\
(4)=(2) *(3)\end{array}$ \\
\hline 1996 & 0.579 & 1.311 & 0.759 \\
\hline 1997 & 0.754 & 1.225 & 0.924 \\
\hline 1998 & 0.804 & 1.145 & 0.921 \\
\hline 1999 & 0.720 & 1.070 & 0.771 \\
\hline 2000 & 0.411 & 1.000 & 0.411 \\
\hline \multicolumn{3}{|c|}{ Present Value Investment Costs to BFRL: } \\
\hline
\end{tabular}

All three summary measures are appropriate for evaluating whether to accept or reject a given research project, yet there are distinctions among them relating to other decision types. PVNS, a magnitude measure, is the best way to evaluate a project's economic merits. With budget constraints, SIR and AIRR are useful in conjunction with the PVNS magnitude measure to help set priorities. SIR and AIRR provide measures of return that, together with PVNS, help ensure consistency in both accepting projects and prioritizing them. ${ }^{21}$

Finally, keep in mind that two potentially significant FDS application benefits did not lend themselves to quantification within the scope of this economic study: increased flexibility in warehouse floorspace layout with removal of draft curtains, and increased competitiveness of the insurance industry with better technical information with which to assess risk. This has led to a conservative estimate of FDS economic impacts. These qualititative benefits should be kept in mind while interpreting the quantitative results.

${ }^{21}$ Chapman, R. E. 2000, pp. 10-12. 


\section{Exhibit 1. Summary of Economic Impacts of BFRL Research on Fire Dynamics Simulation}

\begin{tabular}{|c|c|}
\hline $\begin{array}{l}\text { 1.a Significance of Research Effort: } \\
\text { The Uniform Fire Code (UFC), which serves as a prescriptive model code } \\
\text { for about one-third of the Nation, required three fire protection devices in } \\
\text { warehouses: sprinklers, draft curtains, and roof vents. Property owners } \\
\text { thought these requirements outdated, overly conservative, and costly. Yet } \\
\text { the traditionally-accepted way to evaluate the validity of proposed code } \\
\text { changes involves expensive, time-consuming, full-scale testing-often a } \\
\text { series of } 12 \text { full-scale tests. At the request of large warehouse property } \\
\text { owners including General Motors, Ford, and Home Depot, the NIST/BFRL } \\
\text { Fire Safety Engineering Division undertook research to develop an } \\
\text { application of their Fire Dynamics Simulator (FDS), software that } \\
\text { simulates fire spread and the response of a given sprinkler system, to the } \\
\text { science of sprinkler/draft curtain/roof vent interactions. With a limited } \\
\text { budget for full-scale testing, the idea was to run FDS simulations before } \\
\text { each full-scale test to help design the test to return the most information } \\
\text { possible. The FDS application guided the design of five full-scale tests } \\
\text { conducted at Underwriters Laboratories in } 1997 \text {. The simulation/testing } \\
\text { approach proved successful. It yielded enough scientific evidence to } \\
\text { convince UFC code officials to remove draft curtain requirements for } \\
\text { sprinklered warehouse facilities in 2000. }\end{array}$ & 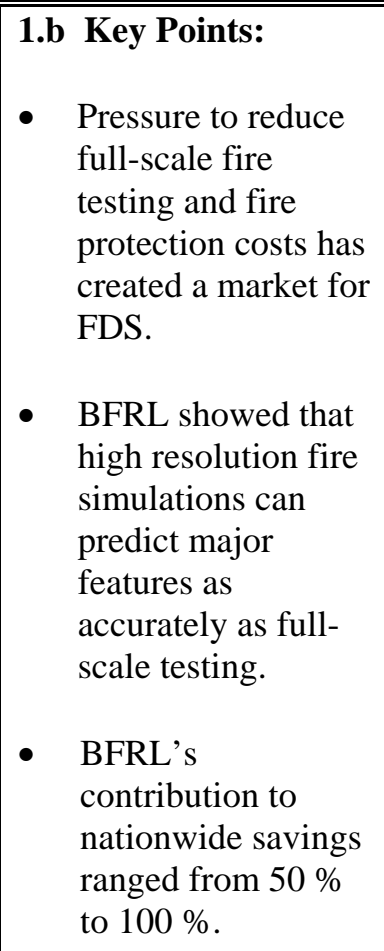 \\
\hline
\end{tabular}

\section{Analysis Strategy: How Key Measures are Estimated}

The objective of the study is to (1) evaluate, for the period 1996 through 2020, the net cost savings due to the removal of draft curtain requirements from the Uniform Fire Code, and (2) estimate BFRL's contribution to these net cost savings. The approach is to estimate in 2000 present value $(P V)$ dollars:

Present Value Cost Savings Nationwide to warehouse property owners that have taken advantage of the removal of draft curtain requirements from the Uniform Fire Code. PV cost savings nationwide are estimated for each year from 1996 to 2020 and summed.

Present Value Savings (PVS) attributable to BFRL by including only the savings that accrued due to BFRL's participation, assuming BFRL's contribution ranged from $50 \%$ to $100 \%$ of nationwide savings.

Present Value Net Savings (PVNS) attributable to BFRL by subtracting from BFRL PVS the present value of BFRL's investment costs (PV Costs). A PVNS $>0$ indicates an economically worthwhile project.

Two additional measures are also estimated:

Savings-to-Investment Ratio (SIR) attributable to BFRL by taking the ratio of BFRL PVS to BFRL PV costs. A ratio $>1$ indicates an economically worthwhile project.

Adjusted Internal Rate of Return (AIRR), the annual rate of return over the study period on BFRL's investment. An AIRR > the discount rate indicates that the project is economically worthwhile. 
Exhibit 1. Summary of Economic Impacts of BFRL Research on Fire Dynamics Simulation (continued)

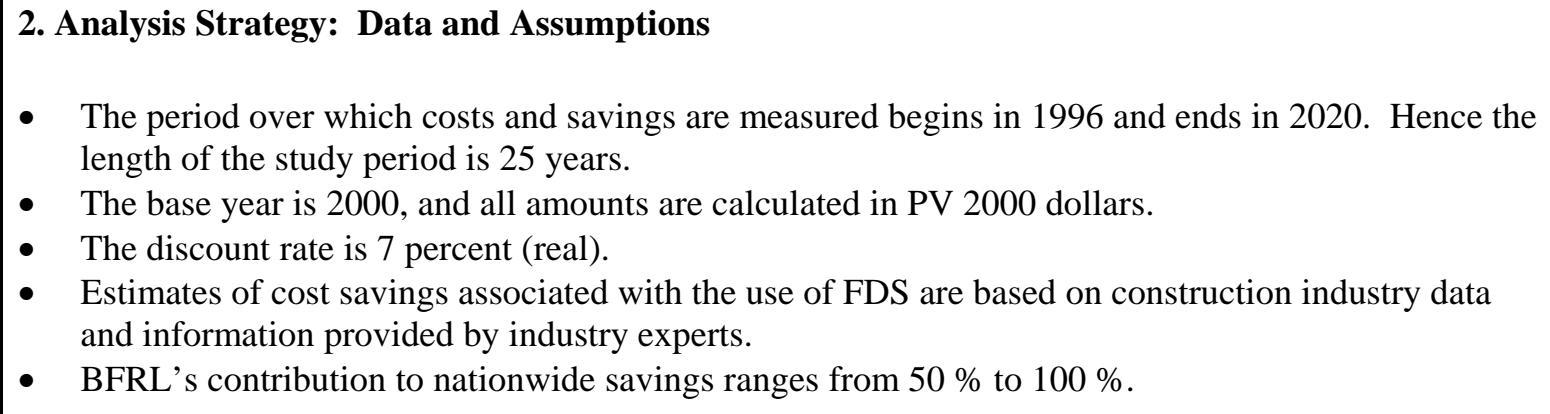

- The period over which costs and savings are measured begins in 1996 and ends in 2020. Hence the length of the study period is 25 years.

- The base year is 2000, and all amounts are calculated in PV 2000 dollars.

- $\quad$ The discount rate is 7 percent (real).

- Estimates of cost savings associated with the use of FDS are based on construction industry data and information provided by industry experts.

- BFRL's contribution to nationwide savings ranges from $50 \%$ to $100 \%$.

3.a Calculation of Savings, Costs, and Additional Measures

\section{Savings and Costs}

Present Value Cost Savings Nationwide:

Sum from 1996 to 2020 of present value of cost savings nationwide by year

$$
=\$ 380.8 \text { million }
$$

Present Value Savings (PVS) Attributable to BFRL:

Sum from 1996 to 2020 of present value of cost savings nationwide by year

$$
=\$ 190.1 \text { million }-\$ 380.8 \text { million }
$$

Present Value Investment Costs (PV Costs) to BFRL:

Sum from 1996 to 2000 of present value of investment cost to BFRL by year

$$
=\$ 3.785 \text { million }
$$

Present Value Net Savings (PVNS) Attributable to BFRL: Difference between present value savings (PVS) attributable to BFRL and present value of investment costs (PV Costs) to BFRL

$=\$ 186$ million $-\$ 377.0$ million

\section{Additional Measures}

\section{SIR of BFRL Contribution:}

Savings-to-Investment Ratio on BFRL investment

$$
=50.24-100.61
$$

AIRR of BFRL Contribution:

Adjusted Internal Rate of Return on BFRL investment

$$
=0.251-0.287
$$

3.b Key Results:

2000 Dollars

(\$ amounts in millions)

Cost Savings Nationwide:

$\$ 380.8$

Savings Attributable to

BFRL:

PVS $\quad \$ 190.1-\$ 380.8$

PV Costs \$3.785

PVNS \$186-\$377.0

SIR $\quad 50.24-100.61$

AIRR $\quad 25.1 \%-28.7 \%$ 


\section{Sensitivity Analysis of Economic Impacts}

There are several ways to account for uncertainty in a benefit-cost analysis. They include breakeven analysis, conservative benefit and cost estimating, decision analysis, and sensitivity analysis. This economic impact study has already employed the conservative benefit and cost estimating approach in its baseline analysis, consistently setting values for deriving applicable warehouse floorspace and research investment costs such that any errors due to uncertainty result in an underestimation of the FDS application's economic worth. In this chapter, sensitivity analysis will be employed for one key input value about which there is significant uncertainty: draft curtain costs. For the purposes of this analysis, the BFRL contribution to nationwide savings is assumed to be $100 \%$. Sensitivity analysis tests the impact on results of changes in values of one or more key variables about which there is uncertainty. It is widely used in government and private sector studies, and is cited as one way for Federal agencies to account for uncertainty in OMB Circular A-94. In this chapter, a deterministic sensitivity analysis is done, recalculating benefits using pessimistic and optimistic values for draft curtain costs to see how they change the three economic impact measures developed in the baseline analysis for the $100 \%$ BFRL contribution scenario. ${ }^{22}$

Draft curtain costs vary widely due to a number of factors: (1) warehouse size (curtain cost per unit of floorspace decreases as floorspace increases due to economies of scale), (2) flexibility in designing and installing ceiling utilities such as lighting, ductwork, and sprinkler systems, (3) type of warehouse occupancy - retail or industrial, (4) contractor profit rates, and (5) local labor and material costs. As reported in Chapter 3, draft curtains cost at least $\$ 4.31 / \mathrm{m}^{2}\left(\$ 0.40 / \mathrm{ft}^{2}\right)$ to install, exlusive of hidden costs, and at most $\$ 14.64 / \mathrm{m}^{2}\left(\$ 1.36 / \mathrm{ft}^{2}\right)$ to install, including hidden costs. Also, recall that in a national context, contractor profit rates should be deducted from draft curtain cost savings because removing draft curtain requirements has the disadvantage of lowering contractor profit. As noted in Chapter 3, contractor profit rates range from $5 \%$ to $15 \%$. A pessimistic value for draft curtain cost, one resulting in the lowest cost savings, assumes no hidden costs and a maximum contractor profit rate, and an optimistic value assumes hidden costs and a minimum contractor profit rate. For this sensitivity analysis a pessimistic draft curtain cost savings, net of maximum profit, is $\$ 3.66 / \mathrm{m}^{2}$ ( $\$ 0.34 / \mathrm{ft}^{2}$ ) and an optimistic cost savings, excluding minimum profit, is $\$ 13.89 / \mathrm{m}^{2}$ ( $\left.\$ 1.29 / \mathrm{ft}^{2}\right)$. For the $100 \%$ BFRL contribution scenario, tables 6 and 7 recompute Present Value Savings Attributable to BFRL based on these pessimistic and optimistic values, respectively.

Using from tables 6 and 7 the pessimistic and optimistic values for Present Value Savings Attributable to BFRL (PVS), the three economic impact measures-Present Value Net Savings Attributable to BFRL (PVNS), Savings-to-Investment Ratio on the BFRL Investment (SIR), and Adjusted Internal Rate of Return of the BFRL Investment (AIRR) - are recomputed. The Present

\footnotetext{
${ }^{22}$ Chapman, R. E. 1996, pp. 23-25.
} 
Table 6. Sensitivity Analysis: Present Value Savings Attributable to BFRL based on Pessimistic Draft Curtain Savings, in 2000 \$

\begin{tabular}{|c|c|c|c|c|c|c|}
\hline $\begin{array}{l}\text { Year } \\
(1)\end{array}$ & $\begin{array}{c}\text { Net Draft Curtain } \\
\text { Cost Savings } \\
\text { in } \$ / \mathrm{m}^{2}\left(\$ / \mathrm{ft}^{2}\right) \\
(2)\end{array}$ & $\begin{array}{c}\text { Applicable } \\
\text { Floorspace } \\
\mathrm{M} \mathrm{m}^{2}\left(\mathrm{M} \mathrm{ft}^{2}\right) \\
(3)\end{array}$ & $\begin{array}{c}\text { Total Cost } \\
\text { Savings } \\
\$ \mathrm{M} \\
(4)=(2)^{*}(3)\end{array}$ & $\begin{array}{c}\text { NFPRF Testing } \\
\text { Costs } \\
\$ \mathrm{M} \\
(5) \\
\end{array}$ & $\begin{array}{c}\text { Discount Factor } \\
(6)\end{array}$ & $\begin{array}{c}\text { Present Value } \\
\text { Cost Savings } \\
\$ \mathrm{M} \\
(7)=(4) *(6) \\
\end{array}$ \\
\hline \multicolumn{7}{|l|}{1996} \\
\hline 1997 & & & & 0.479 & 1.225 & $-0.586^{\mathrm{b}}$ \\
\hline \multicolumn{7}{|l|}{1998} \\
\hline \multicolumn{7}{|l|}{1999} \\
\hline 2000 & $3.66(0.34)$ & $3.9(41.5)$ & 14.12 & & 1.000 & 14.12 \\
\hline 2001 & $3.66(0.34)$ & $3.9(41.5)$ & 14.12 & & 0.935 & 13.20 \\
\hline 2002 & $3.66(0.34)$ & $3.9(41.5)$ & 14.12 & & 0.873 & 12.34 \\
\hline 2003 & $3.66(0.34)$ & $3.9(41.5)$ & 14.12 & & 0.816 & 11.53 \\
\hline 2004 & $3.66(0.34)$ & $3.9(41.5)$ & 14.12 & & 0.763 & 10.77 \\
\hline 2005 & $3.66(0.34)$ & $3.9(41.5)$ & 14.12 & & 0.713 & 10.07 \\
\hline 2006 & $3.66(0.34)$ & 3.9 (41.5) & 14.12 & & 0.666 & 9.41 \\
\hline 2007 & $3.66(0.34)$ & $3.9(41.5)$ & 14.12 & & 0.623 & 8.80 \\
\hline 2008 & $3.66(0.34)$ & $3.9(41.5)$ & 14.12 & & 0.582 & 8.22 \\
\hline 2009 & $3.66(0.34)$ & $3.9(41.5)$ & 14.12 & & 0.544 & 7.68 \\
\hline 2010 & $3.66(0.34)$ & $3.9(41.5)$ & 14.12 & & 0.508 & 7.18 \\
\hline 2011 & $3.66(0.34)$ & $3.9(41.5)$ & 14.12 & & 0.475 & 6.71 \\
\hline 2012 & $3.66(0.34)$ & $3.9(41.5)$ & 14.12 & & 0.444 & 6.27 \\
\hline 2013 & $3.66(0.34)$ & $3.9(41.5)$ & 14.12 & & 0.415 & 5.86 \\
\hline 2014 & $3.66(0.34)$ & $3.9(41.5)$ & 14.12 & & 0.388 & 5.48 \\
\hline 2015 & $3.66(0.34)$ & $3.9(41.5)$ & 14.12 & & 0.362 & 5.12 \\
\hline 2016 & $3.66(0.34)$ & $3.9(41.5)$ & 14.12 & & 0.339 & 4.78 \\
\hline 2017 & $3.66(0.34)$ & $3.9(41.5)$ & 14.12 & & 0.317 & 4.47 \\
\hline 2018 & $3.66(0.34)$ & $3.9(41.5)$ & 14.12 & & 0.296 & 4.18 \\
\hline 2019 & $3.66(0.34)$ & $3.9(41.5)$ & 14.12 & & 0.277 & 3.91 \\
\hline 2020 & $3.66(0.34)$ & $3.9(41.5)$ & 14.12 & & 0.258 & 3.65 \\
\hline \multicolumn{6}{|c|}{ Present Value Savings Attributable to BFRL: } & 163.2 \\
\hline
\end{tabular}

${ }^{\mathrm{a}} \mathrm{BFRL}$ is assumed to contribute $100 \%$ to nationwide savings.

${ }^{\mathrm{b}}$ For 1997, present value cost savings is computed by taking the negative of the product of columns (5) and (6). 
Table 7. Sensitivity Analysis: Present Value Savings Attributable to BFRL based on Optimistic Draft Curtain Savings, in 2000 \$

\begin{tabular}{|c|c|c|c|c|c|c|}
\hline $\begin{array}{c}\text { Year } \\
(1)\end{array}$ & $\begin{array}{c}\text { Net Draft Curtain } \\
\text { Cost Savings } \\
\text { in } \$ / \mathrm{m}^{2}\left(\$ / \mathrm{ft}^{2}\right) \\
(2)\end{array}$ & $\begin{array}{c}\text { Applicable } \\
\text { Floorspace } \\
\mathrm{M} \mathrm{m}^{2}\left(\mathrm{M} \mathrm{ft}^{2}\right) \\
\text { (3) }\end{array}$ & $\begin{array}{c}\text { Total Cost } \\
\text { Savings } \\
\text { \$M } \\
(4)=(2) *(3)\end{array}$ & $\begin{array}{c}\text { NFPRF Testing } \\
\text { Costs } \\
\$ M \\
(5) \\
\end{array}$ & $\begin{array}{c}\text { Discount Factor } \\
(6)\end{array}$ & $\begin{array}{c}\text { Present Value } \\
\text { Cost Savings } \\
\text { \$M } \\
(7)=(4) *(6)\end{array}$ \\
\hline \multicolumn{7}{|l|}{1996} \\
\hline 1997 & & & & 0.479 & 1.225 & $-0.586^{b}$ \\
\hline \multicolumn{7}{|l|}{1998} \\
\hline \multicolumn{7}{|l|}{1999} \\
\hline 2000 & $13.89(1.29)$ & $3.9(41.5)$ & 53.67 & & 1.000 & 53.67 \\
\hline 2001 & 13.89 (1.29) & $3.9(41.5)$ & 53.67 & & 0.935 & 50.16 \\
\hline 2002 & $13.89(1.29)$ & $3.9(41.5)$ & 53.67 & & 0.873 & 46.88 \\
\hline 2003 & 13.89 (1.29) & $3.9(41.5)$ & 53.67 & & 0.816 & 43.81 \\
\hline 2004 & $13.89(1.29)$ & $3.9(41.5)$ & 53.67 & & 0.763 & 40.94 \\
\hline 2005 & 13.89 (1.29) & $3.9(41.5)$ & 53.67 & & 0.713 & 38.26 \\
\hline 2006 & 13.89 (1.29) & $3.9(41.5)$ & 53.67 & & 0.666 & 35.76 \\
\hline 2007 & $13.89(1.29)$ & $3.9(41.5)$ & 53.67 & & 0.623 & 33.42 \\
\hline 2008 & $13.89(1.29)$ & $3.9(41.5)$ & 53.67 & & 0.582 & 31.24 \\
\hline 2009 & $13.89(1.29)$ & $3.9(41.5)$ & 53.67 & & 0.544 & 29.19 \\
\hline 2010 & $13.89(1.29)$ & $3.9(41.5)$ & 53.67 & & 0.508 & 27.28 \\
\hline 2011 & $13.89(1.29)$ & $3.9(41.5)$ & 53.67 & & 0.475 & 25.50 \\
\hline 2012 & $13.89(1.29)$ & $3.9(41.5)$ & 53.67 & & 0.444 & 23.83 \\
\hline 2013 & $13.89(1.29)$ & $3.9(41.5)$ & 53.67 & & 0.415 & 22.27 \\
\hline 2014 & 13.89 (1.29) & $3.9(41.5)$ & 53.67 & & 0.388 & 20.81 \\
\hline 2015 & $13.89(1.29)$ & $3.9(41.5)$ & 53.67 & & 0.362 & 19.45 \\
\hline 2016 & $13.89(1.29)$ & $3.9(41.5)$ & 53.67 & & 0.339 & 18.18 \\
\hline 2017 & $13.89(1.29)$ & $3.9(41.5)$ & 53.67 & & 0.317 & 16.99 \\
\hline 2018 & $13.89(1.29)$ & $3.9(41.5)$ & 53.67 & & 0.296 & 15.88 \\
\hline 2019 & 13.89 (1.29) & $3.9(41.5)$ & 53.67 & & 0.277 & 14.84 \\
\hline 2020 & $13.89(1.29)$ & $3.9(41.5)$ & 53.67 & & 0.258 & 13.87 \\
\hline \multicolumn{7}{|c|}{ Present Value Savings Attributable to BFRL: } \\
\hline
\end{tabular}

${ }^{\mathrm{a}} \mathrm{BFRL}$ is assumed to contribute $100 \%$ to nationwide savings.

${ }^{\mathrm{b}}$ For 1997, present value cost savings is computed by taking the negative of the product of columns (5) and (6). 
Value of Investment Costs to BFRL (PV Costs) remains set at its baseline value (\$3.785 million), as do the study period (1996-2020) and discount rate (7\% real). Table 8 shows the results by displaying the economic impact measures under the pessimistic, baseline (100 \% BFRL contribution), and optimistic settings for draft curtain costs. As shown, PVNS ranges from $\$ 159.4$ to $\$ 617.9$ million, SIR ranges from 43.11 to 164.25 , and AIRR ranges from $24.4 \%$ to $31.2 \%$. The sensitivity analysis shows that, even under the pessimistic scenario, the FDS application was still an economically worthwhile project. Under this scenario, the Present Value Net Savings Attributable to BFRL, PVNS, is $\$ 159.4$ million, showing the dollar value to the public net of FDS-application investments. The Savings-to-Investment Ratio of the BFRL Contribution, SIR, is 43.11 , showing that the public receives $\$ 43.11$ dollars for each public dollar spent on the FDS application. The Adjusted Internal Rate of Return of the BFRL Contribution, AIRR, is 0.244 , showing a $24.4 \%$ return on public dollars spent on FDS application development throughout the study period.

\section{Table 8. Summary: BFRL Contribution to Cost Savings from Removal of Draft Curtain Requirements from Uniform Fire Code, 1996-2020 ${ }^{\mathrm{a}}$}

\begin{tabular}{|c|c|c|c|}
\hline $\begin{array}{c}\text { Measure of Economic Worth } \\
\text { (\$ amounts in million 2000 \$) }\end{array}$ & $\begin{array}{c}\text { Average } \\
\text { Curtain Costs } \\
\text { (Most likely) }\end{array}$ & $\begin{array}{c}\text { Pessimistic } \\
\text { Curtain Costs } \\
\text { (Conservative) }\end{array}$ & $\begin{array}{c}\text { Optimistic } \\
\text { Curtain Costs } \\
\text { (Hopeful) }\end{array}$ \\
\hline PVS: Total BFRL Contribution & $\$ 380.8$ & $\$ 163.2$ & $\$ 621.6$ \\
\hline PVNS: Net BFRL Contribution & $\$ 377.0$ & $\$ 159.4$ & $\$ 617.9$ \\
\hline SIR: BFRL Contribution & 100.61 & 43.11 & 164.25 \\
\hline AIRR: BFRL Contribution & 0.287 & 0.244 & 0.312 \\
\hline
\end{tabular}

${ }^{a}$ For this exercise, BFRL is assumed to contribute $100 \%$ to nationwide savings. 


\section{Future Directions}

This case study lays the groundwork for future economic analyses of NIST fire research. An economic profile of the U.S. fire protection industry was developed, identifying and defining all the costs and benefits of fire protection, by stakeholder group. The profile provided the context within which a subset of benefits, costs, and stakeholders affected by the overall FDS research program could be identified. The subset was narrowed further to identify those benefits and costs affected by the particular FDS application that was the focus of this case study. While the case study showed significant economic benefits to the Nation of the sprinkler/draft curtain/roof vent application, even greater benefits are expected from other FDS research applications. The sprinkler/draft curtain/roof vent application has raised industry's expectations about the potential of fire simulation to decrease fire protection costs and increase safety. Already, there are signs that new FDS applications are taking root. In the 8 months since the FDS software has been publicly available, approximately 940 individuals have downloaded the tool from the NIST web site. The simulation software is being used for applications ranging from explaining actual fires to developing performance-based design solutions for unique facilities for which prescriptive codes do not exist. For example, Gage-Babcock \& Associates has applied FDS to the historic Arts and Industries Building (AIB) on the National Mall in Washington, D.C. As they report in Fire Protection Engineering, ${ }^{23}$

"The fire model used for the analysis, Fire Dynamics Simulator (FDS) version 1.0 , represents a significant advancement in modeling the effects of fire in complex buildings such as the AIB...The emergence of performance-based codes and analytical tools such as advanced fire modeling provides a means for identifying acceptable solutions."

With continued research funding, FDS has the potential to revolutionize fire protection engineering. An economic analysis quantifying the benefits and costs of other potential FDS applications is recommended to justify and set optimal levels for future FDS research expenditures.

Additionally, the economic profile of the U.S. fire protection industry developed for this case study provides a useful framework for considering potential economic impacts of other BFRL fire research efforts. As BFRL management strives to set appropriate research priorities under limited budgets, the framework could prove a useful organizing tool in two ways: (1) for qualitatively predicting and comparing economic worth for competing fire research proposals, and (2) for conducting formal, quantitative case studies of ongoing or proposed fire research efforts. Increasingly, managers are asked to demonstrate economic impact to justify, manage, and attract internal and external support for its research programs. The framework developed here is a logical starting point for launching future economic studies of BFRL fire research.

\footnotetext{
${ }^{23}$ Bowman, A. Fall 2000. "Performance-Based Analysis of an Historic Museum.” Fire Protection Engineering. Bethesda, MD: Society of Fire Protection Engineers, pp. 38,43.
} 


\section{References}

American Society for Testing and Materials. Fourth Edition, 1999. ASTM Standards on Building Economics. West Conshohocken, PA: American Society for Testing and Materials.

Baum, H. R. Spring 2000. "Large Eddy Simulations of Fires: From Concepts to Computations.” Fire Protection Engineering. Bethesda, MD: Society of Fire Protection Engineers, pp. 36-43.

Bowman, A. Fall 2000. "Performance-Based Analysis of an Historic Museum.” Fire Protection Engineering. Bethesda, MD: Society of Fire Protection Engineers, pp. 36-43.

Chapman, R. E., and S. K. Fuller. 1996. Benefits and Costs of Research: Two Case Studies in Building Technology. NISTIR 5840. Gaithersburg, MD: National Institute of Standards and Technology.

Chapman, R.E., and S.F. Weber. 1996. Benefits and Costs of Research: A Case Study of the Fire Safety Evaluation System. NISTIR 5863. Gaithersburg, MD: National Institute of Standards and Technology.

Chapman, R. E. 1999. Benefits and Costs of Research: A Case Study of Cybernetic Building Systems. NISTIR 6303. Gaithersburg, MD: National Institute of Standards and Technology.

Chapman, R. E. 2000. Benefits and Costs of Research: A Case Study of Construction Systems Integration and Automation Technologies in Industrial Facilities. NISTIR 6501. Gaithersburg, MD: National Institute of Standards and Technology.

McGrattan, K. B., Hamins, A., and D. W. Stroup. 1998. Sprinkler, Smoke and Heat Vent, Draft Curtain Interaction: Large Scale Experiments and Model Development. NISTIR 6196-1.

Gaithersburg, MD: National Institute of Standards and Technology.

OMB A-94: Executive Office of the President. 1992. OMB Circular A-94. Washington, DC: Office of Management and Budget

R.S. Means Company, Inc., 1999. 2000 Building Construction Cost Data, on CD-ROM of Means 2000 CostWorks. Kingston, MA.

Ramachandran, G. 1998. The Economics of Fire Protection. London: E \& FN Spon.

U.S. Department of Energy, Commercial Buildings Energy Consumption Survey.

U.S. Department of Labor. 2000. Consumer Price Index, on Internet at http://stat.bls.gov/cpihome.htm. Washington, D.C. 